\title{
UNDERSTANDING LINK BETWEEN LAND SURFACE TEMPERATURE AND LANDSCAPE HETEROGENEITY: A SPATIO-TEMPORAL AND INTER-SEASONAL VARIABILITY STUDY ON KABUL CITY, AFGHANISTAN
}

\author{
S. Mahmoodi ${ }^{1, *}$, K. Dutta ${ }^{2}$, D. Basu ${ }^{3}$, S. Agrawal $^{4}$ \\ ${ }^{1}$ Department Of Civil Engineering, Motilal Nehru National Institute of Technology Allahabad, Prayagraj, Uttar Pradesh 211004, \\ India - sebghatkhursand@ gmail.com \\ ${ }^{2}$ GIS Cell, Motilal Nehru National Institute of Technology Allahabad, Prayagraj, Uttar Pradesh 211004, India - \\ rgi1604@mnnit.ac.in \\ ${ }^{3}$ Department Of Civil Engineering, Motilal Nehru National Institute of Technology Allahabad, Prayagraj, Uttar Pradesh 211004, \\ India - basud@mnnit.ac.in \\ ${ }^{4}$ GIS Cell, Motilal Nehru National Institute of Technology Allahabad, Prayagraj, Uttar Pradesh 211004, India - \\ sonam@mnnit.ac.in
}

\section{Commission V, WG V/7 \& Commission IV, WG IV/6}

KEY WORDS: Land Surface Temperature, Land Use Land Cover, Aerosols, Land Management, Kabul

\begin{abstract}
:
Satellite imageries were used to study temporal and seasonal patterns of Land Surface Temperature (LST) in Kabul, followed by establishing an interrelation with Land Use Land Cover (LULC) changes occurring in the city. LULC and LST changes were examined based on Landsat Thematic Mapper (TM) and Landsat Operational Land Imager (OLI), Thermal Infrared Sensors (TIRS). LST Maps were derived from the thermal band of Landsat images for decadal study (Winter/Summer; 2008-09 and 201819). Visible bands were utilized for supervised LULC classification in the same decade. Results showed that Kabul City expanded rapidly over the study period from $232.28 \mathrm{~km}^{2}$ to $371.08 \mathrm{~km}^{2}$ in one decade (2009-2019). Other land cover classes i.e. barren land, mountains and vegetation, were observed to be converted to urban class i.e. residential, commercial, and industrial. High LST zones of Kabul city consisted of mountains, barren land and urban areas. Notable difference of $3^{\circ} \mathrm{C}$ was observed between urban and vegetated lands. This study successfully identified the areas (i.e. district 12, district 13 and district 17) currently affected by rapid urban sprawl. The results also highlighted the changes in LST pattern caused by urbanization. The study will help the government, private sector investors and land planners to develop sustainable land management policies.
\end{abstract}

\section{INTRODUCTION}

Remote sensing (RS) plays a primary role in land management and planning by providing information on the physical characteristics of land, as well as monitor changes in allocation of land parcels to various uses. This may have a direct bearing on the land cover heterogeneity and prevailing environmental conditions of an area. Hence, such specific data procured through RS would influence land management by successful integration into infrastructure planning. Preparation of resource maps and inventory generation through acquisition of temporal information are key to efficient monitoring necessary in sustainable land management practices. Information on prevalent natural resources management system can be further reviewed with the help of thorough temporal analysis for reformation or formulation of policies and administrative procedures related to land management practices. Satellite images of Landsat, Spot, Modis, IRS etc. have been widely applied for sustainable land use and natural resource management, through change detection and monitoring environmental degradation on spatio-temporal scale. This has proved to be essential for urban planners in developing policy related to change in land cover as a result of anthropogenic activity; thereby, checking and controlling human activities and adverse impacts of rapid urban development. With increasing land scarcity, such applications are especially useful for land suitability studies. The rampant changes in land cover, i.e. deliberate conversion mainly by deforestation, for agriculture, urbanization; have been responsible for changes in regional and as well as global climate.
Land Surface Temperature (LST) is defined as the effective radiating skin temperature of the earth's surface with reference to soil surface temperature for bare soil; canopy surface temperature for densely vegetated ground; temperature of vegetation canopy, vegetation body and soil surface for sparse vegetated ground (Khandelwal et al., 2018). The rapid pace of urbanization is responsible for major changes in the Land Use Land Cover (LULC) pattern over the past few decades. Another significant cause for LULC change is due to the growth in size and number of cities as a result of urban sprawl. Drastic conversion of classes like vegetation, water bodies, wasteland and agricultural land to the built-up areas is prevalent in several studies conducted over the last few years. The drastic rise in LST is strongly attributed to the LULC changes due to rapid urbanization leading to disturbed habitat unfit for humans and other living beings. LST being sensitive to various land surface features; can be used to extract information on different LULC types (Sinha et al., 2015). Use of historic and current spatial or attribute data in urban growth analysis, is an essential requirement for future scientific planning of cities and the establishment of political policies for substantial city development (Dadras et al., 2015). Numerous studies have been conducted on application of remote sensing for detection of seasonal and temporal changes in LST as well as LULC (Hathout, 2002); (Lambin et al., 2003); (Deng et al., 2009);(Shen et al., 2015). Significant variation in LST over various LULC types have been observed for Malda District in West Bengal, India by (Pal and Ziaul, 2016), which shows $2.75^{\circ} \mathrm{C}$ increase in LST on the rate of $0.114^{\circ} \mathrm{C} /$ year $(1991-$ 2014). The impact of LULC changes were obtained for land

*Corresponding Author 
surface temperature in Karst area of China by (Xiao and Weng, 2007), reporting that Guiyang and Qingzhen in 1991 had a temperature of $291.1 \mathrm{~K}$ and $288.6 \mathrm{~K}$, respectively. This increased to $294.2 \mathrm{~K}$ and $292.9 \mathrm{~K}$, respectively. However, the spatio-temporal transiency and non-uniformity in LST makes it very important to correlate this parameter with other stable environmental features like land cover and surface terrain attributes i.e. slope, aspect and terrain position (Fan et al., 2014).

The objective of the work outlined in the paper is to determine the dynamics of LST in relation to the LULC alteration over the past decade through spatio-temporal analysis for Kabul City, Afghanistan. The capital city of Afghanistan was selected as a case study, due its typical surface terrain conditions and semi-arid climate; necessitating one of very few researches conducted to study the seasonal and temporal variability of LST with suitable linkages to other influencing parameters like the land-use induced land cover change and elevation difference. LST has been retrieved from thermal images by the mono window method. Significant areas were identified for immediate attention with respect to continuous monitoring and developing mitigatory measures for efficient land management practices. The study aims to demonstrate application of RS and GIS for generation of thermal and land cover data for improving land management and policy formulation.

\section{STUDY AREA}

Kabul is the capital city of Afghanistan with 22 districts. Kabul is the political, cultural and intellectual centre. It is the largest city of Afghanistan with $36 \%$ urbanization. It is located between $34^{\circ} 39^{\prime} \mathrm{N}$ to $34^{\circ} 17^{\prime} \mathrm{N}$ latitude and $69^{\circ} 29^{\prime} \mathrm{E}$ to $68^{\circ} 54^{\prime} \mathrm{E}$ longitude, as shown in Figure 1,. This study is conducted on an area of $1033.3 \mathrm{~km}^{2}$ with a population of approximately five million with growth rate of $3.91 \%$ per year. Kabul city land surface has a texture of sandy soil and rocky mountains. This city is surrounded by mountains.

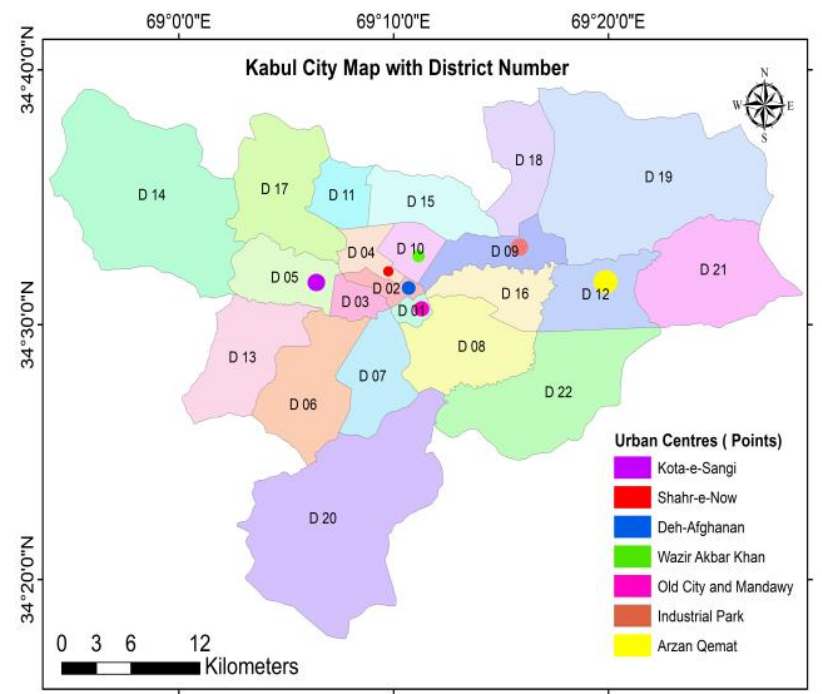

Figure 1. Kabul city map with district number

\section{DATA USED}

Data of Landsat-TM-5 and Landsat-8 OLI-TIRS are selected to detect changes of urban expansion and to evaluate the LST changes related to the urbanization expansion in Kabul. For the seasonal variability study of Kabul City, imageries were obtained for the most critical months of the seasons, December and July/August, representing both winter and summer season. Cloud free imageries were downloaded from United States Geological Survey (USGS) server, for the dates 10 December 2008 and 22 July 2009 Landsat TM-5 and for the dates 06 December 2018 and 03 August 2019 Landsat-8 OLI-TIRS with path 153 and row 36. OLI-TIRS has bands with resolution of $30 \mathrm{~m}$ and thermal bands of $100 \mathrm{~m}$ resolution while all bands of TM sensor have resolution of $30 \mathrm{~m}$ with exception of thermal band which has a resolution of $120 \mathrm{~m}$.

\section{MEHTODOLOGY}

For extracting surface temperature from thermal band of Landsat imageries and classification of different land covers the following methodology has been used (Figure 2.).

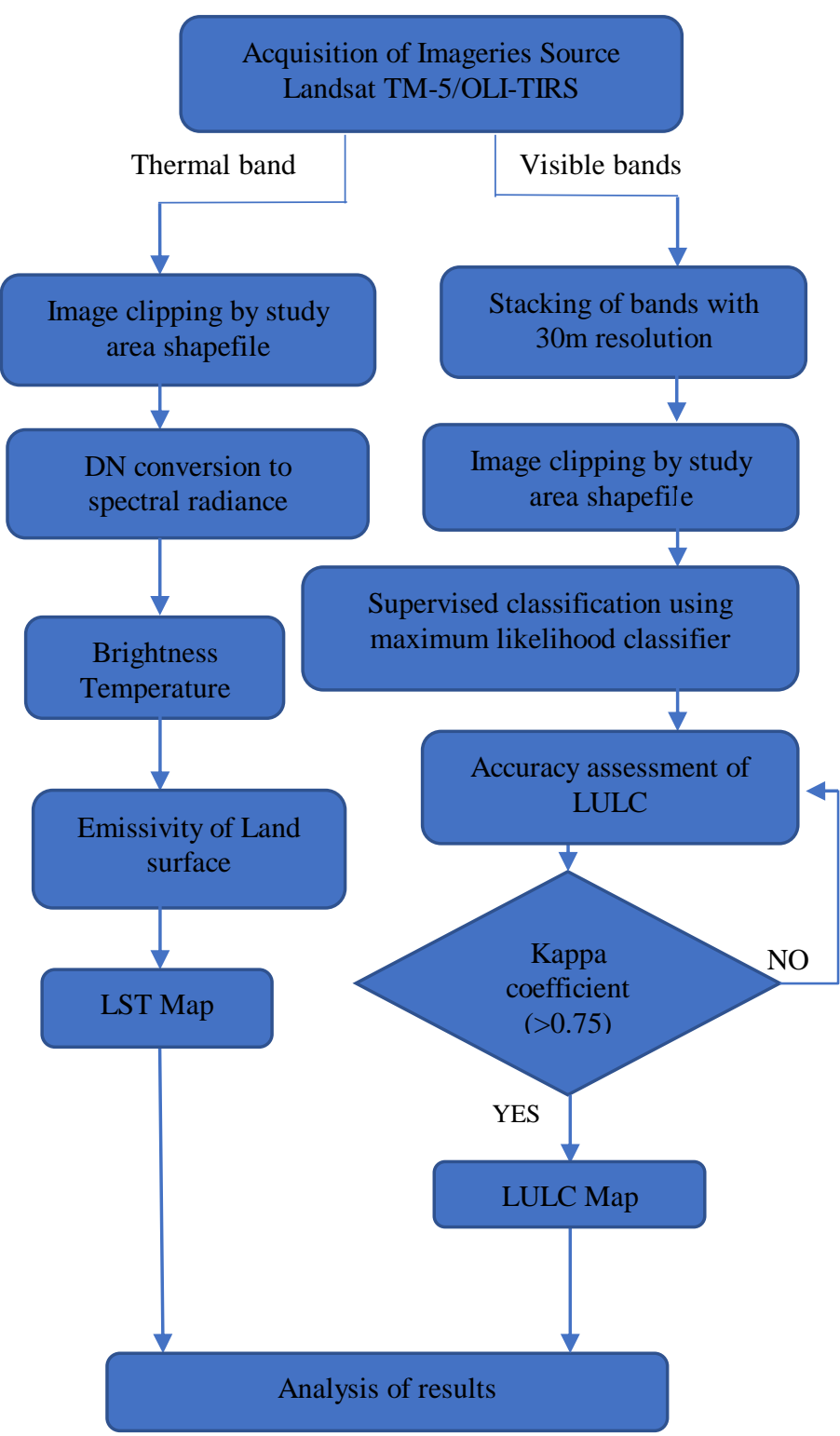

Figure 2. Flowsheet of detailed methodology 


\subsection{LST Mapping}

\subsubsection{Clipping of Study Area}

Clip is used to extract the study area. In this paper, the study area is clipped with city boundary provided by Kabul Municipality from the imageries downloaded from USGS.

\subsubsection{DN Conversion to Spectral Radiance}

It includes the conversion of pixel DN (Digital Number) to atsensor radiance, subtraction of atmospheric illumination effects and sensor calibration. While comparing multiple imageries it is better to use spectral radiance rather than using DN values directly. The conversion is carried out with the following formula (NASA, 2011).

$$
\begin{aligned}
& \mathrm{L} \lambda=[(\operatorname{LMax} \lambda-\operatorname{LMin} \lambda) /(\mathrm{QCalMax}-\mathrm{QCalMin})] *(\mathrm{QCal}- \\
& \mathrm{QCalMin})+\operatorname{LMin} \lambda
\end{aligned}
$$

where

$\mathrm{L} \lambda=$ spectral radiance at the sensor's aperture in $\mathrm{W} /(\mathrm{m} 2 \mathrm{sr} \mu \mathrm{m})$

$\operatorname{LMax} \lambda=$ spectral radiance that is scaled to QCalMax in $\mathrm{W} /(\mathrm{m} 2 \mathrm{sr} \mu \mathrm{m})$

$\operatorname{LMin} \lambda=$ spectral radiance that is scaled to QCalMin in $\mathrm{W} /\left(\mathrm{m}_{2} \mathrm{sr} \mu \mathrm{m}\right)$

$\mathrm{QCal}=$ quantized calibrated pixel value in digital number

QCalMax = maximum quantized calibrated pixel value in digital number

QCalMin $=$ minimum quantized calibrated pixel value in digital number

It has been proved that radiation correction improves the accuracy of LST (Song et al., 2000).

\subsubsection{Brightness Temperature}

The spectral radiance converted from pixel DN values is then used to compute brightness temperature (i.e. blackbody temperature) under the assumption of unit emissivity and using pre-launch calibration constants (NASA, 2011).

$$
\mathrm{TB}_{\mathrm{K}}=\mathrm{K}_{2} / \ln \left(1+\left(\mathrm{K}_{1} / \mathrm{L} \lambda\right)\right)
$$

where

$$
\begin{aligned}
& \mathrm{TB}_{\mathrm{K}}=\text { Effective at satellite temperature in Kelvin } \\
& \mathrm{TB}_{\mathrm{C}}=\text { Effective at satellite temperature in Degree } \\
& \text { Celsius } \\
& \mathrm{K}_{1} \text { and } \mathrm{K}_{2}=\text { pre-launch calibration constants } \\
& \text { For TM, } \mathrm{K}_{1}=607.76 \text { and } \mathrm{K}_{2}=1260.56 \\
& \text { For OLI/TIRS, } \mathrm{K}_{1}=774.8853 \text { and } \mathrm{K}_{2}=1321.0789
\end{aligned}
$$

\subsubsection{Emissivity of Land Surface}

The temperature obtained from equation (2) is for black body, which is different from the real land surface temperature. Therefore, emissivity correction must be applied. Land surface emissivity were estimated as follows: for with NDVI $<0.2$, the emissivity was assumed as to be 0.98 ; while for NDVI $>0.5$, the emissivity was assumed as to be 0.99 ; for those with $0.2 \leq$ $\mathrm{NDVI} \leq 0.5$ (Wang et al., 2018) the emissivity was given as,

$$
\varepsilon=0.004 \cdot \mathrm{Pv}+0.986
$$

where

$\mathrm{Pv}$ was the vegetation proportion obtained according to the equation (4).

$$
\mathrm{P}_{\mathrm{v}}=\left(\left(\mathrm{NDVI}-\mathrm{NDVI} \mathrm{I}_{\min }\right) /\left(\mathrm{NDVI} \mathrm{I}_{\max }-\mathrm{NDVI}_{\min }\right)\right)^{2}
$$

where

$\mathrm{NDVI}_{\min }=0.2, \mathrm{NDVI}_{\max }=0.5$ were given in previous studies (Wang et al., 2018)

Normalized Difference Vegetation index is computed with equation (5)

$\mathrm{NDVI}=(\mathrm{NIR}-\mathrm{Red}) /(\mathrm{NIR}+\mathrm{Red})$

For Landsat OLI-TIRs-8 this can be written as: NDVI $=[($ Band $5-$ Band 4$) /($ Band $5+$ Band 4$)]$

For Landsat TM- 5 this can be written as: NDVI $=[($ Band $4-$ Band 3$) /($ Band $4+$ Band 3$)]$

\subsubsection{Land Surface Temperature (LST)}

LST was calculated from the Brightness temperature ( $\mathrm{Li}$ et al., 2009) by applying emissivity correction as in equation (6).

$$
\mathrm{LST}=\frac{\mathrm{TB}}{1+\lambda T B \operatorname{Ln\varepsilon } / \rho}-273.15
$$

Where

$\lambda=11.5 \mu \mathrm{m}$ the wavelength of was emitted radiance; $\rho=\mathrm{h} \times \mathrm{c} / \sigma=1.438 \times 10^{-2} \mathrm{mK}, \sigma=5.67 \times 10^{-8} \mathrm{Wm}^{-2}$ $\mathrm{K}^{-4}$ was Stefan Boltzmann's constant; and h, c and $\varepsilon$ were the Planck's constant, the velocity of light, the land surface emissivity, respectively.

\subsection{LULC mapping}

\subsubsection{Stacking of Visible Bands}

Layer stacking is putting all layers above each other which is essential for classifying the different classes. For Landsat TM, the bands from one to five with resolution of $30 \mathrm{~m}$ have been stacked together. For Landsat-8 OLI/TIRS the bands from one to nine with a resolution of $30 \mathrm{~m}$ have been stacked together.

\subsubsection{Supervised Classification}

This paper follows the LULC classification system with four level 1 classes (Anderson, 1975). Two additional class of road and mountains were also included. Maximum likelihood classifier is used to classify the different classes. Supervised classification requires previously known sample to train the classifier and to classify unknown data.

\subsubsection{Accuracy Assessment of LULC}

To get the accurate results of LULC classification the accuracy assessment is performed on the images generated from supervised classification. 350 points have been taken on the classified image of each year (2009 and 2019) and compared with the ground truth obtained from the Google Earth images of the respective year. Post-classification refinements were 
applied to lessen classification errors caused by the similarities in spectral responses of certain classes such as barren land and urban (Harris and Ventura, 1995). Area of Interest (AOI) tool was applied to the classified image using visual analysis from Google Earth and local knowledge to split and recode these covers so to reflect their true classes.

\subsubsection{LULC Map}

The land use and land cover map show the different classes present on an area. LULC map gives a highlighted color to each class to distinguish between different classes. This paper use red for urban, yellow for vegetation, magenta for barren land, brown for mountains, blue for water and black for roads.

\subsubsection{Analysis of Results}

The change detection is the process of finding differences between two remote sensed images which are taken in different point of time (Zhang et al., 2016).

\section{RESULT AND DISCUSSION}

\subsection{Seasonal Analysis of LST}

The land surface temperature profile for Kabul City was prepared for analyzing the seasonal and temporal variability in

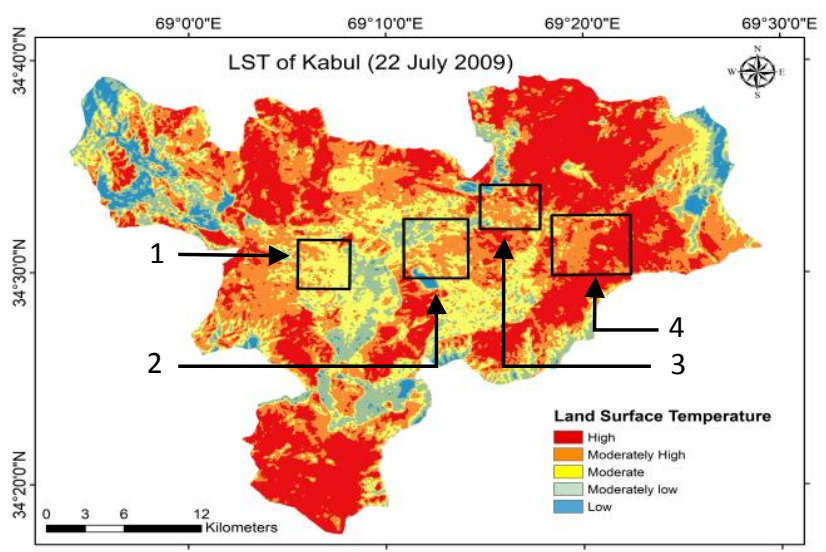

Figure 3. LST profile of Kabul summer 2009

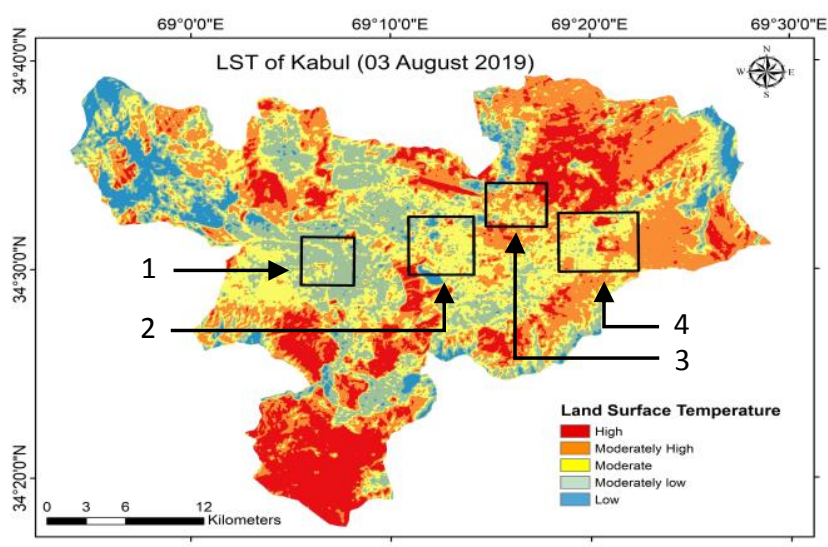

Figure 4. LST profile of Kabul summer 2019 different land use/cover classes. The built-up class (including residential, commercial, industrial and roads network) showed an increase of $+1.45^{\circ} \mathrm{C}$ for summer season during the decadal analysis (2009-2019), as seen from (Figure 3 and 4). Similarly, the decadal study for winter season (2008-2018) showed that there was an overall increase of $+1.66^{\circ} \mathrm{C}$ (Figure 5 and 6). The effect of anthropogenic activity can be assumed as an important factor for the overall increase in the surface temperature as observed through such decadal analysis.

A similar observation can be made to corroborate the above explanation. The temperature obtained particularly for the Industrial park located in district 9 shows increased winter temperature of $+1.11^{\circ} \mathrm{C}$ for decade $(2008-2018)$. Also, it was observed in the decadal analysis for summer season, that there was an increase of $+2.9^{\circ} \mathrm{C}$ for decade (2009-2019).

In drier climates during summer, the net radiation intake increases resulting in intense surface warming effect. The absence of cloud cover and decrease in moisture available for evaporative cooling contributes to higher surface temperatures. Similar effects of cloud cover on surface temperature was previously reported by Feng and Zou (2019).

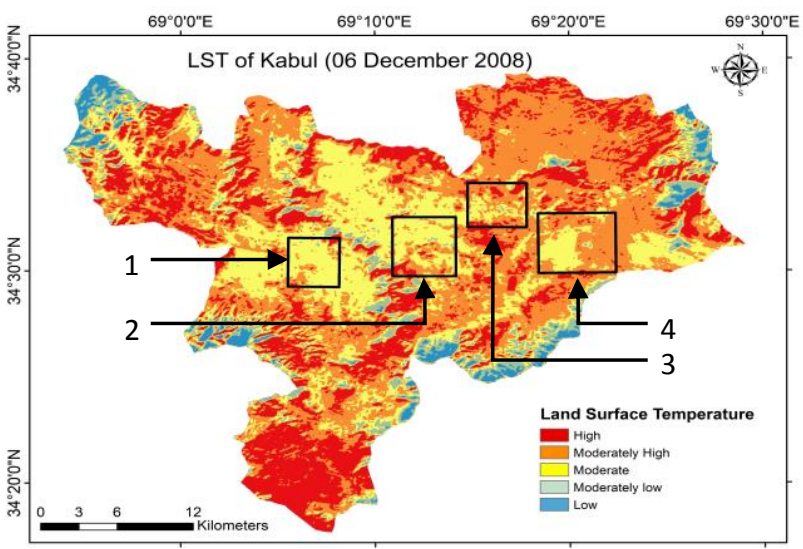

Figure 5. LST profile of Kabul winter 2008

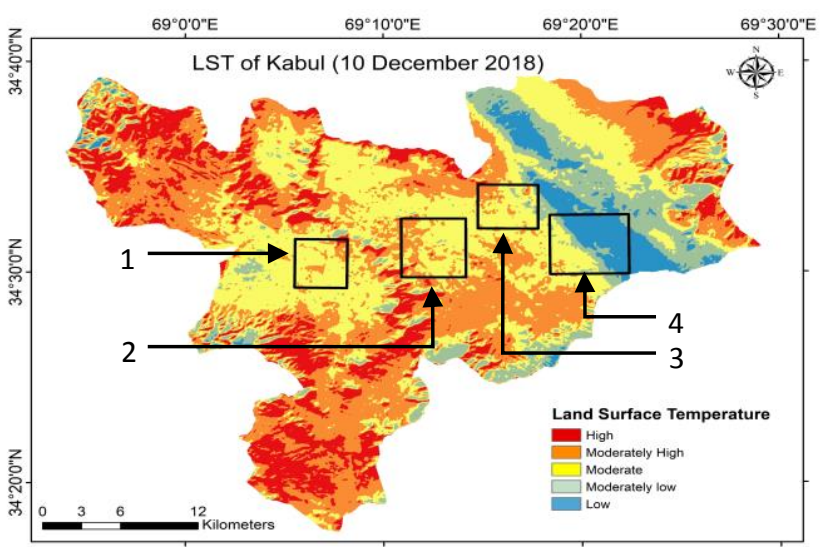

Figure 6. LST profile of Kabul winter 2018 
Kabul being partly cloudy in winters, in contrast to summers, may result in cooler surfaces. The city had experienced heavy snowfall in winter 2018. The distinct regions of low temperature were typically observed in barren lands and mountain peaks for the same year in winter due to thick layers of settled snow (Figure 6). This can be attributed to the higher albedo of snow, in comparison to the average albedo of land surface. In barren lands with sparse vegetation, lower evapotranspiration and greater radiation result in decreased latent heat and thereby warmer surfaces. The rapid heating of sandy soil (barren land) and rocky mountains showed highest temperatures in the range of $10.01-11.25^{\circ} \mathrm{C}$ in winter (2008-18) and $40.5-43.5^{\circ} \mathrm{C}$ in summer $(2009-19)$ for these two classes relative to other classes.

The LST for significant urban areas (based on their contribution towards commercial, industrial, administrative, residential use) were analyzed for summer and winter season (Table 1). The boxes shown on LST maps provide spatial reference for these critical urban locations. Box one shows Kota-e-Sangi (commercial) area, box three shows Industrial park and box 4 shows Arzan Qemat (residential) area. Similarly, Box 2 shows Shahr-e-Now (commercial), Wazir Akbar Khan (residential), Deh Afghanan (administrative), Old city (residential) and Manadawy (commercial) areas.

\begin{tabular}{|l|l|l|l|l|}
\hline \multirow{2}{*}{ Prime Points } & \multicolumn{4}{|c|}{ Average Temperature ${ }^{\circ} \mathrm{C}$ ) } \\
\cline { 2 - 5 } & $\begin{array}{l}\text { Summer } \\
\text { (22 Jul, } \\
\text { 2009) }\end{array}$ & $\begin{array}{l}\text { Summer } \\
\mathbf{3 A u g ,} \\
\mathbf{2 0 1 9})\end{array}$ & $\begin{array}{l}\text { Winter } \\
\mathbf{1 0 ~ D e c ,} \\
\mathbf{2 0 0 8})\end{array}$ & $\begin{array}{l}\text { Winter } \\
\text { (6 Dec, } \\
\mathbf{2 0 1 8})\end{array}$ \\
\hline Shahr-e-Now (D 4) & 34.85 & 36.27 & 5.93 & 8.36 \\
\hline $\begin{array}{l}\text { Wazir Akbar } \\
\text { Khan (D10) }\end{array}$ & 32.55 & 36.33 & 6.21 & 7.22 \\
\hline Kota-e-Sangi (D 5) & 34.00 & 35.00 & 6.72 & 8.13 \\
\hline $\begin{array}{l}\text { Arazan Qemat } \\
\text { (D 12) }\end{array}$ & 34.28 & 37.29 & 6.44 & 7.85 \\
\hline $\begin{array}{l}\text { Deh Afghanan } \\
\text { (D 2) }\end{array}$ & 32.78 & 35.41 & 5.12 & 6.58 \\
\hline $\begin{array}{l}\text { Old city and } \\
\text { Mandawy (D 1) }\end{array}$ & 34.94 & 37.84 & 5.60 & 7.36 \\
\hline $\begin{array}{l}\text { Industrial park } \\
\text { (D 9) }\end{array}$ & 37.32 & 40.22 & 7.43 & 8.54 \\
\hline
\end{tabular}

Table 1. LST for major urban centers

The air quality status may have direct bearing on the LST of a city. The reported high levels of ambient air pollution in Kabul City may be attributed to use of low-quality, inexpensive, more polluting fuel sources by residents and local industries as a result of power rationing within the city (Sharkey et al., 2016). Additionally, emissions from open burning of biomass and from heavy vehicular traffic on unpaved roads, may contribute to black carbon type aerosols promoting radiation absorption. Such aerosols evaporate the atmospheric moisture enabling more solar radiation to reach the surface (Stofferahn and Boybeyi, 2017). Mineral and dust aerosols having diameter less than $10 \mu \mathrm{m}$, originate from barren lands or deserts (Lau et al., 2006). They have also been reported to exhibit absorbing characteristics by various researchers (Tariq and Ali, 2015),
(Vandenbussche and De Mazière, 2017). These aerosols are found at lower altitudes (below $7 \mathrm{~km}$ ) due to their size, in contrast to the mineral ash particles, that are found up to an altitude of $20 \mathrm{~km}$ ((Maes et al., 2016);(Tsamalis et al., 2013)). However, the overall effect on increase in LST may be influenced due to non-absorbing aerosols, as they will reflect more incoming solar radiation, thereby, cooling the surface (Seinfeld et al., 2016).

\subsection{Temporal Analysis of LST}

In 2019, the temperature for all classes of land cover were found to increase by more than $+1.45^{\circ} \mathrm{C}$. The most populated and central business areas of Kabul had an average increase of $+2.46{ }^{\circ} \mathrm{C}$ in the last ten years (2009-2019). Old city (District 01) had an increase of $+2.9^{\circ} \mathrm{C}$. Deh Afghanan (District 02), Shahri Now (District 04), Kota-e-Sangi (District 05), Wazir Akbar Khan (District 10) and Arzan Qemat (District 12) had an increase of $+2.63{ }^{\circ} \mathrm{C},+1.42{ }^{\circ} \mathrm{C},+1{ }^{\circ} \mathrm{C},+3.78{ }^{\circ} \mathrm{C}$ and +3.01 ${ }^{\circ} \mathrm{C}$ respectively in the same decade (Table 1 ).

\subsection{LULC Mapping}

LULC maps were generated for 2009 and 2019 as shown in figure 8 and 9 respectively. Table 2 is showing the change in area which is obtained by the temporal analysis of the LULC map of the study area. As compare to year 2009 (Figure 8), the urban area is increased by $138.80 \mathrm{~km}^{2}$ by the year 2019 (Figure9). Also, there is a significant decrease in the barren land which mostly consists of rocky, stony and sandy region. It has decreased by $122.85 \mathrm{~km}^{2}$ within the time period of 10 years. To study about the LULC conversion a transition probability matrix is also prepared which is shown in Table 5. It can be seen from the matrix that the conversion of other classes into the urban area is very high. The conversion of water, barren land, vegetation and mountain into the urban class is $26 \%$, $36 \%, 21 \%$ and $12 \%$, respectively. Therefore, it is clear that there is a rapid urban expansion in the Kabul city at the cost of natural resources like water and vegetation.

\begin{tabular}{|c|c|c|c|c|c|c|}
\hline \multirow{2}{*}{ LULC Class } & \multicolumn{2}{|c|}{ Area $\left(\mathbf{k m}^{2}\right)$} & \multirow{2}{*}{$\begin{array}{l}\text { Change in } \\
\text { Area }\left(\mathbf{k m}^{2}\right)\end{array}$} & \multicolumn{3}{|c|}{ Change in Area } \\
\hline & 2009 & 2019 & & $2009 \%$ & $2019 \%$ & $\Delta \%$ \\
\hline Road & 6.06 & 10.94 & 4.88 & 0.588 & 1.062 & 0.474 \\
\hline Water & 4.71 & 4.17 & -0.54 & 0.45 & 0.405 & -0.053 \\
\hline Barren land & 258.48 & 135.63 & -122.85 & 25.09 & 13.16 & -11.926 \\
\hline Vegetation & 114.17 & 115.50 & 1.33 & 11.08 & 11.213 & 0.129 \\
\hline Mountains & 414.40 & 392.77 & -21.62 & 40.22 & 38.12 & -2.099 \\
\hline Urban & 232.28 & 371.08 & 138.80 & 22.54 & 36.024 & 13.47 \\
\hline
\end{tabular}

Table 2. LULC decadal changes (2009-2019)

The accuracy of LULC classification for both the years was checked. The confusion matrices to compute the overall accuracy of LULC classification for 2009 and 2019 are shown in Table 3 and 4 respectively. 


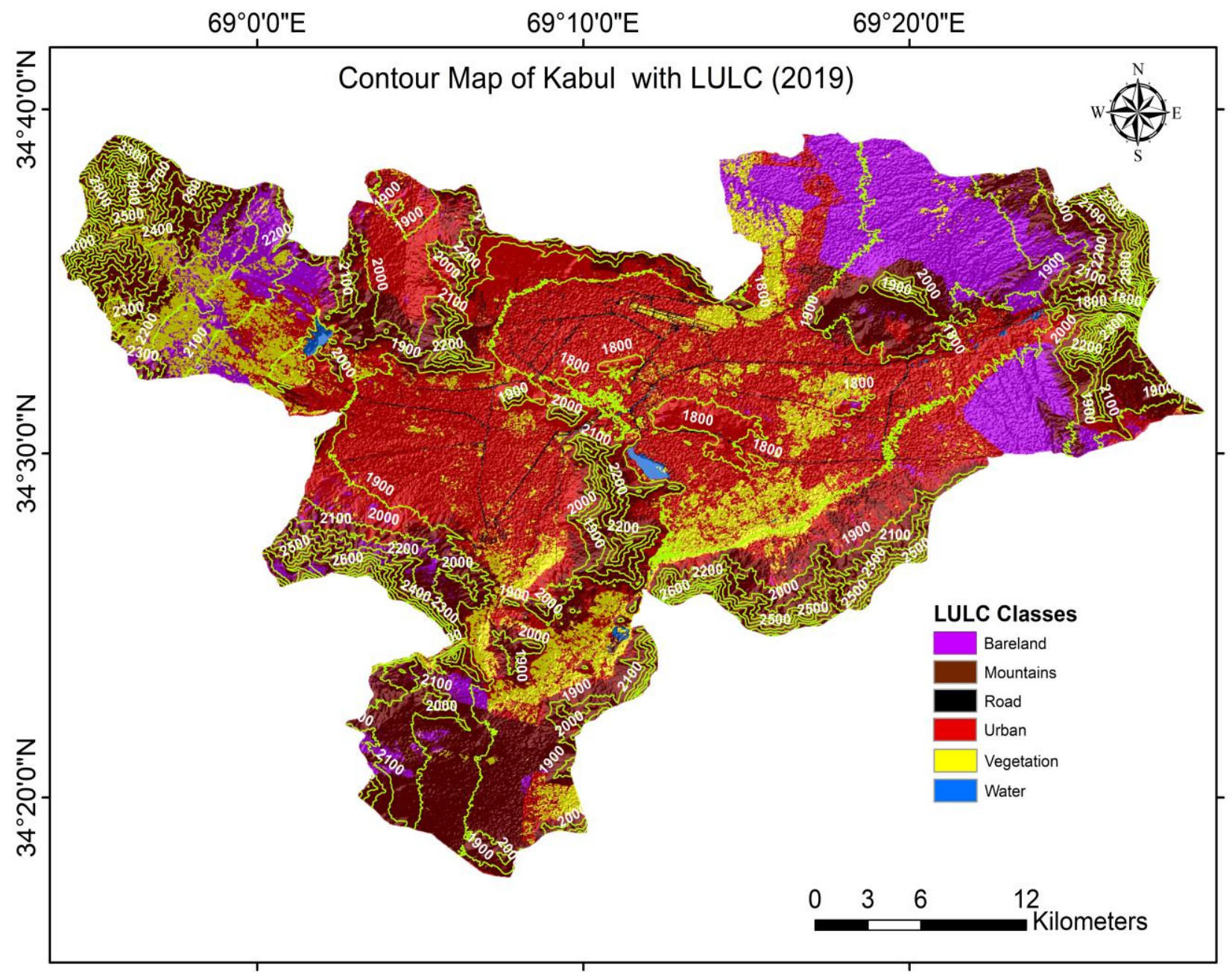

Figure 7. LULC map of Kabul with contour
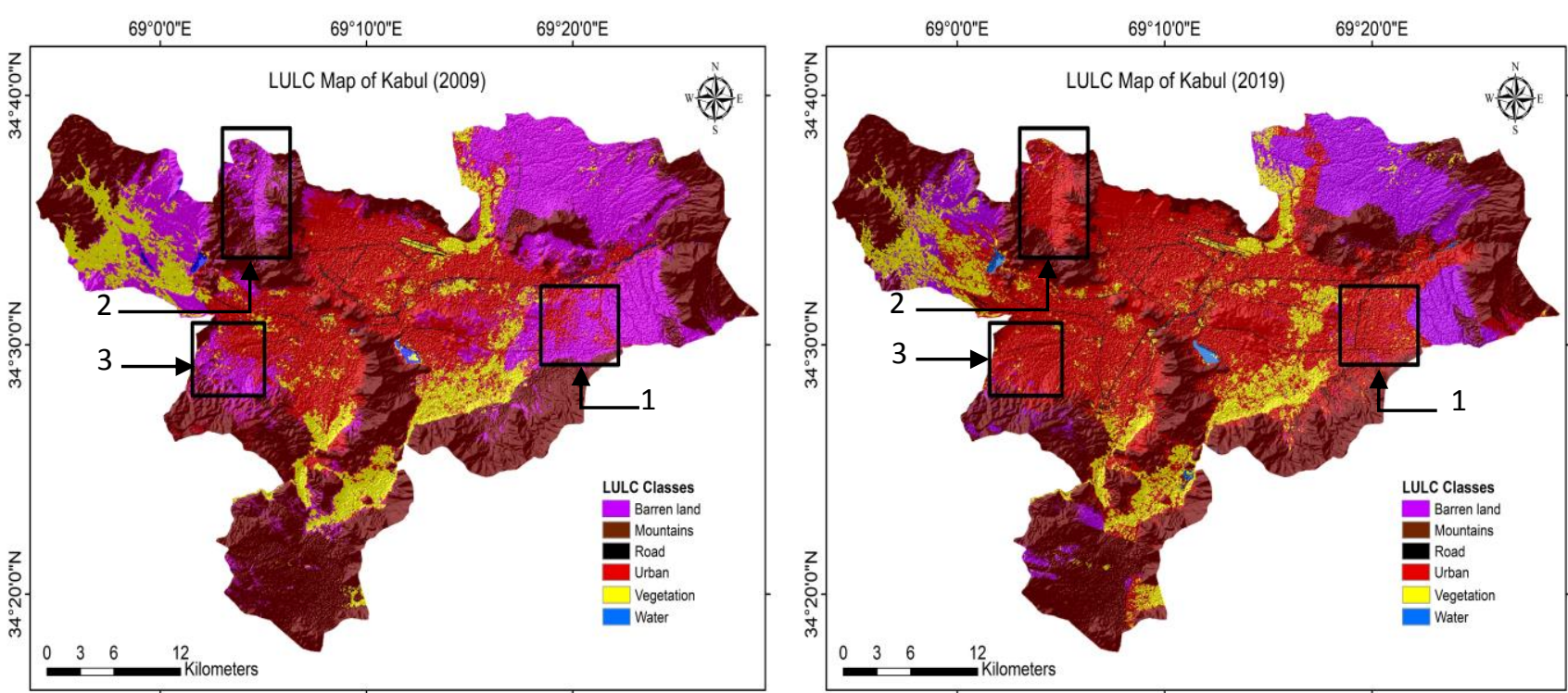

Figure 8. LULC map of Kabul 2009

Figure 9. LULC map of Kabul 2019 


\begin{tabular}{|c|c|c|c|c|c|c|c|}
\hline & UB & MN & VG & BL & WR & RD & $\begin{array}{c}\text { Accuracy } \\
\text { \% }\end{array}$ \\
\hline UB & 80 & 1 & 0 & 4 & 0 & 0 & 94 \\
\hline MN & 3 & 92 & 0 & 5 & 0 & 0 & 92 \\
\hline VG & 0 & 0 & 50 & 0 & 0 & 0 & 100 \\
\hline BL & 2 & 2 & 0 & 51 & 0 & 0 & 93 \\
\hline WR & 1 & 1 & 1 & 0 & 27 & 0 & 89 \\
\hline RD & 0 & 0 & 0 & 0 & 0 & 30 & 100 \\
\hline \multicolumn{7}{|c|}{ Over all Accuracy }
\end{tabular}

*UB (Urban), MN (Mountains), VG (Vegetation), BL (Barren Land), WR (Water), RD (Road).

Table 3. Confusion matrix of LULC classification 2009

\begin{tabular}{|c|c|c|c|c|c|c|c|}
\hline & UB* & MN* & VG* $^{*}$ & BL$^{*}$ & WR$^{*}$ & RD $^{*}$ & $\begin{array}{c}\text { Accuracy } \\
\text { \% }\end{array}$ \\
\hline UB & 115 & 0 & 0 & 5 & 0 & 0 & 95 \\
\hline MN & 0 & 57 & 0 & 3 & 0 & 0 & 95 \\
\hline VG & 0 & 0 & 50 & 0 & 0 & 0 & 100 \\
\hline BL & 3 & 1 & 0 & 49 & 0 & 0 & 92 \\
\hline WR & 0 & 0 & 1 & 0 & 28 & 0 & 96 \\
\hline RD & 1 & 0 & 0 & 0 & 0 & 37 & 97 \\
\hline \multicolumn{7}{|c|}{ Over all Accuracy } \\
\hline
\end{tabular}

Table 4. Confusion matrix of LULC classification 2019

For both the years the accuracy achieved was satisfactory and the Kappa coefficients were 0.98 and 0.97 for 2009 and 2019 respectively. Hence post-classification change analysis was conducted on these maps. There is $61 \%$ increase in the urban area from 2009 to 2019. Ahmad Shah Baba Mena (Arzan Qemat) and Dashti Shina Wa Bagrami located in the east of Kabul in District 12 and16 (box 1) have expanded by 22.76 $\mathrm{km}^{2}$ in this decade. This expansion was observed in the area of altitude less than $1800 \mathrm{~m}$ as shown in figure 7 . The northern edge of Kabul, District 17 (box 2) representing Bustan-e Kabul, Chamtala and Bagh-e Aref Khan, expanded by 20.34 $\mathrm{km}^{2}$. All extended urban areas in this district are found along the mountain slopes at an altitude of more than 1900m (Figure 7). The western edge of Kabul District 13 (box 3) showing areas namely Dasht-e Barchi, Pul-e Khushk, Haji Nowruz town and Omid-e Sabz town, expanded by $14.51 \mathrm{~km}^{2}$ along the mountain slope at higher altitudes of $1900 \mathrm{~m} \mathrm{-2000m} \mathrm{(Figure}$ 7). Barren land was found to decrease by $44.1 \%$, due to its conversion to urban and vegetation as shown in figure 9 . The major decrease in barren land was seen in District 12, District 13 and District 17. The LULC changes among the various classes are not mutually exclusive. To check the rate of transition from one land cover class to another the transition probability matrix was prepared and is shown in Table 5. Very high rate of conversion was noted from barren land to urban. Between 2009 and 2019, barren land to urban conversion composed $36.4 \%$ of the total conversion.

\begin{tabular}{|c|c|c|c|c|c|c|}
\hline & RD $^{*}$ & WR $^{*}$ & BL$^{*}$ & VG* $^{*}$ & MN* & UB* \\
\hline RD & 0.464 & 0.008 & 0.013 & 0.021 & 0.022 & 0.469 \\
\hline WR & 0.041 & 0.471 & 0.044 & 0.078 & 0.101 & 0.263 \\
\hline BL & 0.003 & 0.001 & 0.448 & 0.043 & 0.139 & 0.364 \\
\hline VG & 0.001 & 0.007 & 0.035 & 0.717 & 0.023 & 0.214 \\
\hline MN & 0.001 & 0.001 & 0.029 & 0.010 & 0.830 & 0.127 \\
\hline UB & 0.028 & 0.001 & 0.014 & 0.074 & 0.039 & 0.842 \\
\hline
\end{tabular}

Table 5. Transition matrix of LULC classes

\subsection{Interrelationship between LST and LULC}

The average LST per LULC class have been outlined in (Table 6). Of all the LULC classes, mountains and barren lands have been noted with highest average temperature, through decadal study. In arid environments, the top soil characteristics have an anomalous influence on the temporal changes in LST. Some of the land surface features have been observed to show same LST on a specific time period, but, exhibit significant variations at other time periods depending on the prevailing season (Shalaby and Tateishi, 2007). In general, urban or builtup areas had a temperature higher than the surrounding vegetation and water bodies, in summer season i.e. on 22 July, 2009. The LST profile is well known to be closely related to the percentage of impervious surface area in the urban class (Wang et al., 2018). However, some places near to water bodies or vegetation had temperature less than average urban temperature. Places near to Qargha lake had a temperature of $34.57^{\circ} \mathrm{C}$. Minimum, average and maximum temperature of each season (summer and winter) for the year 2009 and 2019 is given in Table 7.

\begin{tabular}{|c|c|c|c|c|}
\hline \multirow{3}{*}{ LULC Class } & \multicolumn{4}{|c|}{ Land Surface Temperature $\left({ }^{\circ} \mathrm{C}\right)$} \\
\cline { 2 - 5 } & $\begin{array}{c}\mathbf{2 2} \text { July } \\
\mathbf{2 0 0 9}\end{array}$ & $\begin{array}{c}\mathbf{0 3} \text { Aug } \\
\mathbf{2 0 1 9}\end{array}$ & $\begin{array}{c}\mathbf{1 0} \text { Dec } \\
\mathbf{2 0 0 8}\end{array}$ & $\begin{array}{c}\mathbf{0 6} \text { Dec } \\
\mathbf{2 0 1 8}\end{array}$ \\
\hline Urban & 35.72 & 37.17 & 7.12 & 8.78 \\
\hline Mountains & 40.51 & 43.47 & 10.01 & 11.25 \\
\hline Vegetation & 31.95 & 34.5 & 6.46 & 7.78 \\
\hline Barren Land & 39.15 & 42.85 & 8.63 & 9.84 \\
\hline water & 24.27 & 28.68 & 4.69 & 6.12 \\
\hline Road & 36.9 & 37.23 & 8.04 & 9.31 \\
\hline
\end{tabular}

Table 6. LST decadal changes in 10 years

\begin{tabular}{|c|c|c|c|c|c|c|c|c|c|c|c|c|}
\hline \multirow[b]{2}{*}{$\frac{2}{5}$} & \multicolumn{3}{|c|}{$\begin{array}{c}\text { LST Summer } \\
(2009)\end{array}$} & \multicolumn{3}{|c|}{$\begin{array}{c}\text { LST Summer } \\
(2019) \\
\end{array}$} & \multicolumn{3}{|c|}{$\begin{array}{l}\text { LST Winter } \\
(2008-2009)\end{array}$} & \multicolumn{3}{|c|}{$\begin{array}{l}\text { LST Winter } \\
(2018-2019)\end{array}$} \\
\hline & 家 & 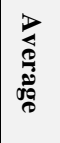 & 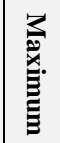 & 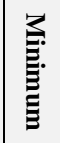 & 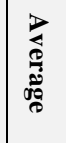 & 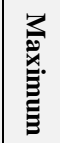 & 裉 & 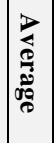 & 主 & 家 & 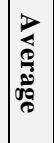 & 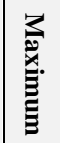 \\
\hline UB $^{*}$ & 24.5 & $\mid 33.8$ & 38.7 & 27.1 & 34.3 & 40.9 & -2.3 & \begin{tabular}{|l|}
6.5 \\
\end{tabular} & 14.2 & -6.7 & \begin{tabular}{|l|} 
\\
\end{tabular} & 19. \\
\hline MN* & 28.8 & \begin{tabular}{|l|}
36.1 \\
\end{tabular} & 45.2 & 34.5 & \begin{tabular}{|l|}
37.3 \\
\end{tabular} & 45.9 & -12.1 & \begin{tabular}{|l|}
7 \\
\end{tabular} & 21.5 & \begin{tabular}{|l}
-14.9 \\
\end{tabular} & \begin{tabular}{|l|}
6.7 \\
\end{tabular} & 22 \\
\hline $\mathbf{V G}^{*}$ & 21.5 & 28.8 & 35.9 & 23.2 & 31.2 & 36.5 & -4 & \begin{tabular}{|l|} 
\\
\end{tabular} & 12.3 & -8 & 4.8 & \begin{tabular}{|l|}
17.2 \\
\end{tabular} \\
\hline $\mathbf{B L}^{*}$ & 27.5 & 36.4 & 43.2 & 34.2 & $\mid 36.7$ & \begin{tabular}{|l}
4.1 \\
\end{tabular} & \begin{tabular}{|l}
-6.3 \\
\end{tabular} & 6.8 & 18.4 & -5.8 & \begin{tabular}{|l|} 
\\
\end{tabular} & 19.8 \\
\hline $\mathbf{W R}^{*}$ & 17.9 & 23.1 & 29.4 & 21.4 & 26.7 & 30.8 & \begin{tabular}{|l}
-2.9 \\
\end{tabular} & 5.1 & 11.2 & -3.8 & \begin{tabular}{|l|} 
\\
\end{tabular} & 15.8 \\
\hline RD $^{*}$ & 26.7 & 34.9 & 41.3 & 30.3 & 35.4 & 43.2 & \begin{tabular}{|l}
-1.8 \\
\end{tabular} & \begin{tabular}{|l|}
6.9 \\
\end{tabular} & \begin{tabular}{|l}
16.7 \\
\end{tabular} & \begin{tabular}{|l}
-6.4 \\
\end{tabular} & \begin{tabular}{|l|}
6.1 \\
\end{tabular} & $\mid 19.4$ \\
\hline
\end{tabular}

Table 7. LST of each season (All values in ${ }^{\circ} \mathrm{C}$ )

\section{CONCLUSION}

In this study, by using multi-temporal Landsat TM and Landsat-8 OLI-TIRS imagery, an integrated approach of remote sensing and GIS has been used for assessment of urban expansion and its impacts on LST profile in Kabul city. Results showed significant increase in urban or built up area from 2009 to 2019. The change in land use land cover caused an increase of $1.45^{\circ} \mathrm{C}$ and $2.55{ }^{\circ} \mathrm{C}$ in summer and an increase of $1.66{ }^{\circ} \mathrm{C}$ and $1.32{ }^{\circ} \mathrm{C}$ in winter, for built up area and vegetation, respectively. The LST porfile of Kabul and its linkage to LULC maps has delienated critical areas undergoing adverse land cover transformation as reflected in terms of elevated surface temperatures. In case of the urban areas, this will be 
directly related to antropogenic activities of development and infrastuctural growth. The findings of the study help to establish interrelationship between LST (temporal and seasonal variation) and LULC as well as other indirect influencing factors i.e. aerosol concentration and type, vegetation intensity, cloud cover and other local climatic factors. This would help in reforming prevailing land management practices and reframe any related policies for the city of Kabul.

\section{REFERENCES}

A Land Use And Land Cover Classification System For Use With Remote Sensor Data, 2001. 2001.

Dadras, M., Shafri, H.Z.M., Ahmad, N., Pradhan, B., Safarpour, S., 2015. Spatio-temporal analysis of urban growth from remote sensing data in Bandar Abbas city, Iran. Egyptian Journal of Remote Sensing and Space Science 18, 35-52. https://doi.org/10.1016/j.ejrs.2015.03.005

Deng, J.S., Wang, K., Hong, Y., Qi, J.G., 2009. Landscape and Urban Planning Spatio-temporal dynamics and evolution of land use change and landscape pattern in response to rapid urbanization 92, 187-198.

https://doi.org/10.1016/j.landurbplan.2009.05.001

Harris, P.M., Ventura, S.J., 1995. The integration of geographic data with remotely sensed imagery to improve classification in an urban area. Photogrammetric Engineering \& Remote Sensing 61, 993-998.

Hathout, S., 2002. The use of GIS for monitoring and predicting urban growth in East and West St Paul, Winnipeg, Manitoba, Canada. Journal of Environmental Management 66 , 229-238. https://doi.org/10.1016/S0301-4797(02)90596-7

Khandelwal, S., Goyal, R., Kaul, N., Mathew, A., 2018. Assessment of land surface temperature variation due to change in elevation of area surrounding Jaipur, India. Egyptian Journal of Remote Sensing and Space Science 21, 87-94. https://doi.org/10.1016/j.ejrs.2017.01.005

Lambin, E.F., Geist, H.J., Lepers, E., 2003. D Ynamics of L and $-\mathrm{U}$ Se and $\mathrm{L}$ and $-\mathrm{C}$ Over $\mathrm{C}$ Hange in T Ropical R Egions . Annual Review of Environment and Resources 28, 205-241. https://doi.org/10.1146/annurev.energy.28.050302.105459

Lau, K.M., Kim, M.K., Kim, K.M., 2006. Asian summer monsoon anomalies induced by aerosol direct forcing: The role of the Tibetan Plateau. Climate Dynamics 26, 855-864. https://doi.org/10.1007/s00382-006-0114-z

Li, J. juan, Wang, Xiang rong, Wang, Xin jun, Ma, W. chun, Zhang, H., 2009. Remote sensing evaluation of urban heat island and its spatial pattern of the Shanghai metropolitan area, China. Ecological Complexity 6, 413-420. https://doi.org/10.1016/j.ecocom.2009.02.002

Maes, K., Vandenbussche, S., Klüser, L., Kumps, N., De Mazière, M., 2016. Vertical profiling of volcanic ash from the 2011 puyehue cordón caulle eruption using IASI. Remote Sensing 8, 1-22. https://doi.org/10.3390/rs8020103

\section{NASA, 2011. Landsat 7 Handbook 186.}

Pal, S., Ziaul, S., 2016. The Egyptian Journal of Remote Sensing and Space Sciences Detection of land use and land cover change and land surface temperature in English Bazar urban centre q. The Egyptian Journal of Remote Sensing and Space Sciences. https://doi.org/10.1016/j.ejrs.2016.11.003

Seinfeld, J.H., Bretherton, C., Carslaw, K.S., Coe, H., DeMott, P.J., Dunlea, E.J., Feingold, G., Ghan, S., Guenther, A.B., Kahn, R., Kraucunas, I., Kreidenweis, S.M., Molina, M.J., Nenes, A., Penner, J.E., Prather, K.A., Ramanathan, V., Ramaswamy, V., Rasch, P.J., Ravishankara, A.R., Rosenfeld, D., Stephens, G., Wood, R., 2016. Improving our fundamental understanding of the role of aerosol-cloud interactions in the climate system. Proceedings of the National Academy of Sciences of the United States of America 113, 5781-5790. https://doi.org/10.1073/pnas.1514043113

Sharkey, J.M., Abraham, J.H., Clark, L.L., Rohrbeck, P., Ludwig, S.L., Hu, Z., Baird, C.P., 2016. Postdeployment Respiratory Health Care Encounters Following Deployment to Kabul, Afghanistan: A Retrospective Cohort Study. Military Medicine 181, 265-271. https://doi.org/10.7205/milmed-d-1400690

Shen, G., Ibrahim, A.N., Wang, Z., Ma, C., 2015. Spatial temporal land-use / land-cover dynamics and their impacts on surface temperature in Chongming Island of Shanghai , China. International Journal of Remote Sensing 36, 4037-4053. https://doi.org/10.1080/01431161.2015.1043404

Song, C., Woodcock, C.E., Seto, K.C., Lenney, M.P., Macomber, S.A., 2000. Classification and Change Detection Using Landsat TM Data: When and How to Correct Atmospheric Effects? 4257.

Stofferahn, E., Boybeyi, Z., 2017. Investigation of aerosol effects on the Arctic surface temperature during the diurnal cycle: part 2 - Separating aerosol effects. International Journal of Climatology 37, 775-787. https://doi.org/10.1002/joc.5075

Tariq, S., Ali, M., 2015. Spatio-temporal distribution of absorbing aerosols over Pakistan retrieved from OMI onboard aura satellite. Atmospheric Pollution Research 6, 254-266. https://doi.org/10.5094/APR.2015.030

Tsamalis, C., Chédin, A., Pelon, J., Capelle, V., 2013. The seasonal vertical distribution of the saharan air layer and its modulation by the wind. Atmospheric Chemistry and Physics 13, 11235-11257. https://doi.org/10.5194/acp-13-11235-2013

Vandenbussche, S., De Mazière, M., 2017. African mineral dust sources: a combined analysis based on 3D dust aerosols distributions, winds and surface parameters. Atmospheric Chemistry and Physics Discussions 1-37. https://doi.org/10.5194/acp-2017-809

Wang, S., Ma, Q., Ding, H., Liang, H., 2018. Detection of urban expansion and land surface temperature change using multi-temporal landsat images. Resources, Conservation and Recycling $\quad 128, \quad 526-534$ https://doi.org/10.1016/j.resconrec.2016.05.011 
Xiao, H., Weng, Q., 2007. The impact of land use and land cover changes on land surface temperature in a karst area of China. Journal of Environmental Management 85, 245-257. https://doi.org/10.1016/j.jenvman.2006.07.016

Zhang, P., Gong, M., Su, L., Liu, J., Li, Z., 2016. ISPRS Journal of Photogrammetry and Remote Sensing Change detection based on deep feature representation and mapping transformation for multi-spatial-resolution remote sensing images. ISPRS Journal of Photogrammetry and Remote Sensing 116, 24-41. https://doi.org/10.1016/j.isprsjprs.2016.02.013 